\title{
LITERASI DIGITAL PADA REMAJA DIGITAL (SOSIALISASI PEMANFAATAN MEDIA SOSIAL BAGI PELAJAR SEKOLAH MENENGAH ATAS)
}

\author{
Nuly Meilinda'), Febrimarani Malinda²), Sari Mutiara Aisyah ${ }^{3)}$
}

\author{
1)2)Jurusan Ilmu Komunikasi, Fakultas Ilmu Sosial Dan Ilmu Politik, Universitas Sriwijaya \\ 3)Jurusan Hubungan Internasional, Fakultas Ilmu Sosial Dan Ilmu Politik, Universitas Sriwijaya \\ Jalan Raya Palembang - Prabumulih KM. 32 Ogan Ilir, Sumatera Selatan. Kode Pos 30662 \\ Email : nurlyml@gmail.com ${ }^{1}$, malinda1102@gmail.com $^{2}$ ), sarimutiara@fisip.unsri.ac.id ${ }^{3)}$
}

\begin{abstract}
ABSTRAK
Perubahan pada tatanan kehidupan masyarakat telah dirasakan sebagai akibat dari masuknya pengaruh internet. Teknologi ini sudah dapat diakses oleh berbagai kalangan masyarakat di Indonesia dengan berbagai lapisan masyarakat dan kategori usia. Begitu hal nya dengan manusia usia remaja yang sedang dalam masa produktif dan inovatif sehingga memiliki rasa keingin-tahuan dalam memperoleh informasi. Segmentasi terbesar dari pengguna internet di Indonesia adalah mereka yang termasuk kedalam kategori remaja, oleh karenanya Pengabdi akan fokus pada remaja yang berusia 13 sampai dengan 17 tahun yang sedang menempuh pendidikan Sekolah Menengah Atas (SMA). Pemahaman akan internet sebagai salah satu bentuk media digital dirasa perlu untuk lebih bijak dalam penggunaannya, peran media digital ini didorong dengan semakin banyaknya media sosial yang memberikan akses informasi bagi remaja dan masyarakat. Sehingga penyebaran informasi akan rentan terhadap segala bentuk ancaman, seperti hoax dan ujaran kebencian. Oleh karenanya, perlu adanya literasi yang harus dipahami dalam kesadaran diri remaja akan penggunaan media digital terutama pada media sosial. Kegiatan sosialisasi terhadap literasi digital dirasa perlu dilakukan khususnya kepada manusia usia remaja sebagai bagian dari komunitas digital. Capaian dalam kegiatan literasi ini dapat mendorong dan mempengaruhi persepsi remaja terhadap pengkonsumsian media informasi dalam bentuk media digital sehingga mampu mengubah kepercayaan dan perilaku remaja.
\end{abstract}

Kata kunci : Sosialisasi, Literasi, Media Digital, Remaja

\section{PENDAHULUAN}

Pada era keterbukaan informasi seperti saat ini, masyarakat Indonesia disuguhkan pada segala jenis informasi tanpa batas. Media Massa mengekspos berita serta tayangan hiburan dengan skala yang masiv. Ditambah lagi dengan lemahnya lembaga pengawasan penyiaran publik yang layaknya mengurangi tayangan yang tidak bermanfaat, menambah semaraknya jenis tayangan kurang mendidik di media massa elektronik. Masalah ini kemudian mengarah pada pembentukan karakter masyarakat Indonesia yang mengacu pada tayangan-tayangan tersebut. Secara khusus masyarakat Banyuasin memiliki karakteristik yang sama dengan kota Palembang, walaupun dengan akses yang lebih terbatas (terutama di bagian pedesaan). Adapun karakter masyarakat Banyuasin yaitu aktif dalam mencari informasi, menyukai hal-hal yang baru, serta senang mendapatkan hiburan. Berdasarkan karakteristik tersebut, maka dipandang perlu untuk memberikan bekal pengetahuan bagi masyarakat Kabupaten Banyuasin, terutama dalam mengkonsumsi media dan memilih tayangan hiburan sebagai sarana aktualisasi diri.

Untuk merealisasikan hal tersebut, perlu ditentukannya khalayak sasaran yang potensial dan dapat digerakkan menjadi agent of change sehingga dapat memberikan perubahan tidak hanya bagi diri sendiri, melainkan juga bagi orang-orang yang tinggal disekelilingnya. Berdasarkan hal ini, maka dipilihlah khalayak sasaran kegiatan yaitu Remaja Usia 14-17 tahun yaitu Siswa di Sekolah Menengah Pertama. Hal ini dianggap lebih efektif karena anak di Usia Remaja ini berada dalam masa pencarian jati diri dan informasi, serta dianggap sebagai usia yang cukup untuk menyerap informasi dan materi yang diberikan. Selain itu anak pada usia ini juga sudah memiliki kekuatan untuk menentukan keputusan bagi dirinya sendiri dan memiliki hak suara dalam keluarga mereka termasuk dalam hal konsumsi media. Melalui kegiatan ini diharapkan para agent of change yang dibentuk dapat 
menjalankan fungsinya di masyarakat dan membantu memecahkan permasalahan lemahnya literasi media di masyarakat.

Indonesia dikenal memiliki keberagaman suku bangsa, bukan hanya itu tapi masyarakat Indonesia juga memiliki keberagaman tingkat kehidupan, tingkat pendidikan, dan juga kebiasaan. Tingkat pendidikan dan kemampuan ekonomi yang rendah dapat mempermudah seseorang untuk dipengaruhi, terutama oleh media massa. Media massa memiliki efek yang sangat kuat dan mampu mempengaruhi persepsi seseorang akan dunia yang dipandangnya, oleh karena itu sangat penting bagi seseorang memiliki filter terhadap konten media massa. Filter terhadap media massa inilah yang disebut dengan literasi media, kemampuan literasi media ini bisa didapat asalkan manusia memiliki informasi dan pemahaman akan konsep tersebut. Oleh karena itu diperlukan tindakan nyata untuk melakukan pemerataan informasi terhadap masyarakat yang memiliki akses media namun tidak disertai dengan pemahaman mengenai literasi media.

Di Indonesia, perubahan dalam tatanan kehidupan masyarakat juga telah dirasakan sebagai akibat dari masuknya pengaruh internet. Teknologi ini sudah dapat diakses oleh berbagai kalangan masyarakat di Indonesia. Semua lapisan masyarakat dari berbagai kategori usia juga telah memiliki kapabilitas dan akses untuk menggunakan internet, utamanya manusia usia remaja yang sedang berada dalam masa produktif dan penuh dengan rasa ingin tahu. Menurut hasil riset nasional yang dilakukan oleh Asosiasi Penyedia Jasa Internet Indones (APJII) dan Pusat Kajian Universitas Indonesia (UI) (2014), mayoritas pengguna internet di Indonesia berada dalam rentang usia 18-25 tahun. Jumlah golongan pengguna muda usia ini bahkan hamper setengah (49\%) dari total jumlah pengguna internet di Indonesia yang mencapai 88,1 juta di tahun 2014 kemarin.

Hal tersebut memperlihatkan bahwa segmen pengguna internet di Indonesia adalah mereka yang termasuk kedalam kategori remaja oleh karena itu Pengabdi akan fokus pada remaja yang berusia 13 sampai 17 tahun yang mayoritas sedang menempuh jenjang pendidikan Sekolah Menangah Atas (SMA). Hal ini disebabkan karena remaja dengan usia tersebut sedang memasuki usia remaja awal dan usia remaja pertengahan, yang menurut Monks (1999) adalah masa dimana remaja masih mencari identitas terhadap kelompok sosialnya, namun belum disertai kematangan fisik dan psikisnya. Lebih lanjut, karya tulis ini akan lebih fokus pada remaja di daerah tertinggal karena usaha pemerintah untuk menyediakan akses internet harus dibarengi dengan pengetahuan tentang media baru tersebut, sehingga masyarakat awam terutama remaja yang menjadi konsumen terbesar internet dapat lebih cerdas dalam menanggapi penyebaran informasi hoax maupun dampak negatif lain yang muncul.

Diperlukan peran berbagai pihak untuk mengembangkanliterasi media yang merupakan kemampuan untuk memahami, menganalisis dan mendekontruksi apa yang disajikan oleh media mengingat pada era keterbukaan informasi seperti saat ini, informasi dapat diakses secara masiv dan tanpa batas. Media Massa mengekspos berita serta tayangan hiburan dengan skala yang masiv. Ditambah lagi dengan lemahnya lembaga pengawasan penyiaran publik yang layaknya mengurangi tayangan yang tidak bermanfaat, menambah semaraknya jenis tayangan kurang mendidik di media massa elektronik. Masalah ini kemudian mengarah pada pembentukan karakter masyarakat Indonesia yang mengacu pada tayangan-tayangan tersebut.

Jadi, dengan jelas terlihat urgensi terhadap literasi media bagi remaja di daerah tertinggal dapat disebabkan oleh beberapa faktor, yaitu:

1. Remaja membutuhkan keterampilan berpikir kritis, mengekspresikan diri dan berpartisipasi dalam media

2. Konsumsi terhadap media dan perkembangan informasi di media memerlukan panduan dan mekanisme dalam menyikapinya

3. Media mempengaruhi kita dalam mempersepsikan sesuatu, membentuk kepercayaan dan mengubah perilaku. Jika kita tahu bagaimana cara media mempengaruhi kita, maka kita akan mengetahui bagaimana menyikapi media dapat mengurangi ketergantungan terhadapnya.

Terkait dengan isu-isu literasi media digital ini dilihat dari beberapa identifikasi masalah sebagai berikut :

1. Banyaknya media massa yang memiliki konten sangat beragam.

2. Kuatnya pengaruh media massa terhadap penggunanya, terutama yang mengandung konten negatif.

3. Kurangnya pemahaman masyarakat akan pentingnya filter terhadap isi media massa.

4. Minimnya peringatan dari lembaga berwenang akan konten media yang dapat mempengaruhi anak-anak dan remaja. 
Oleh karena itu pengabdian ini mempunyai juga beberapa tujuan yang terkait yakni sebagai berikut

1. Mengetahui persepsi siswa tentang konten media massa elektronik, cetak, dan digital

2. Memberikan pemahaman kepada siswa tentang dampak positif dari paparan media yang berlebihan

3. Memberikan pemahaman mengenai literasi media atau melek media Adapun dalam pengabdian ini juga diharapkan dapat meninjau dari segi manfaatnya yaitu adalah :

1. Bagi peserta kegiatan akan mendapatkan pengetahuan mengenai bagaimana mengonsumsi media secara sehat.

2. Dampak secara umum adalah siswa dapat mengonsumsi media secara cerdas sehingga tidak mudah terpengaruh isi media massa, secara makro dapat berujung pada berkurangnya perilaku menyimpang para siswa.

Jadi pengabdian media digital di era/ kaum remaja ini dianggap sangat diperlukan dan dibutuhkan sesuai kebutuhan dari masing-masing penggunaannya, agar remaja tersebut dapat lebih mengetahui tujuan dan manfaat media digital itu sendiri.

\section{METODE PELAKSANAAN PENGABDIAN}

Metode yang digunakan dalam kegiatan pengabdian kepada masyarakat ini bentuknya adalah penyuluhan dan pendampingan dengan materi mengenai dampak positif dan negatif dari media massa dan media sosial, selain itu juga memberikan pemahaman kepada siswa mengenai pentingnya literasi media dan penerapannya ketika mengonsumsi media sosial. Teknik yang dilakukan adalah dengan metode ceramah dengan menggunakan alat peraga interaktif dan metode tanya jawab agar para siswa menjadi lebih mudah mengerti mengenai konsep literasi media tersebut.

\section{HASIL DAN PEMBAHASAN}

Perkembangan dunia digital dapat menimbulkan dua sisi yang berlawanan dalam kaitannya dengan pengembangan literasi digital. Berkembangnya peralatan digital dan akses akan informasi dalam bentuk digital mempunyai tantangan sekaligus peluang. Salah satu kehawatiran yang muncul adalah jumlah generasi muda yang mengakses internet sangat besar, yaitu kurang lebih 70 juta orang. Mereka menghabiskan waktu mereka untuk berinternet, baik melalui telepon genggam, komputer personal, atau laptop, mendekati 5 jam per harinya. Tingginya penetrasi internet bagi generasi muda tentu meresahkan banyak pihak dan fakta menunjukkan bahwa data akses anak Indonesia terhadap konten berbau pornografi per hari rata-rata mencapai 25 ribu orang (Republika, 2017). Belum lagi perilaku berinternet yang tidak sehat, ditunjukkan dengan menyebarnya berita atau informasi hoaks, ujaran kebencian, dan intoleransi di media sosial. Hal-hal tersebut tentu menjadi tantangan besar bagi orang tua, yang mempunyai tanggung jawab dan peran penting dalam mempersiapkan generasi abad ke-21, generasi yang memiliki kompetensi digital (Kemendikbud, 2017).

Disisi lain, perkebangan dunia digital memberikan peluang bagi banyak pihak, mulai dari orang tua hingga anak-anak muda. Peluang ini dapat memberikan efek positif terhadap dunia digital, seperti memunculkan peluang-peluang bisnis (E-commerce) yang sudah banyak mencetak orang-orang sukses dengan memanfaatkan peluang bisnis online. Akibat dari perkembangan teknologi jaringan ini juga memberikan efek pada sektor Pendidikan, dimana aktifitas pembelajaran mulai dikembangkan melalui sistem pembelajaran daring. Selain itu, lapangan pekerjaan yang memanfaatkan dunia digital juga semakin banyak, misalnya dalam bidang transportasi umum online, pengembangan konten youtube, analisis terhadap media sosial, dan lain sebagainya.

Pada perkembangan teknologi informasi dan media sosial lebih memudahkan masyarakat untuk berkomunikasi dengan cepat. Pada massa modernisasi, Media sosial memiliki peranan penting dalam mendistribusikan sebuah informasi. Hal ini lah yang mendorong generasi digital mempunyai karakteristik yang lebih kuat dalam pemanfaat media digital ini, dimana mereka cenderung aktif dalam media sosial seperti facebook, twitter, path, instagram, youtube, dan lain-lain. Generasi ini mempunyai sikap yang cenderung lebih terbuka, blak-blakan, serta berfikir lebih kritis dan agresif. Mereka memilih berekspresi bebas di sosial media dan tidak menyukai jika harus diatur atau dikekang. Media komunikasi seperti handphone, tablet dan smart komputer lainnya menjadi teman 
keseharian mereka, secara fisik mereka akan tampak autis dan menyendiri, namun kenyataannya pikiran mereka tengah berjalan menelusuri sisi kehidupan baru yang disebut dengan dunia maya.

Seperti data gambar yang di bawah ini yang dikutip dalam laman internet world stats.com sebagai berikut :

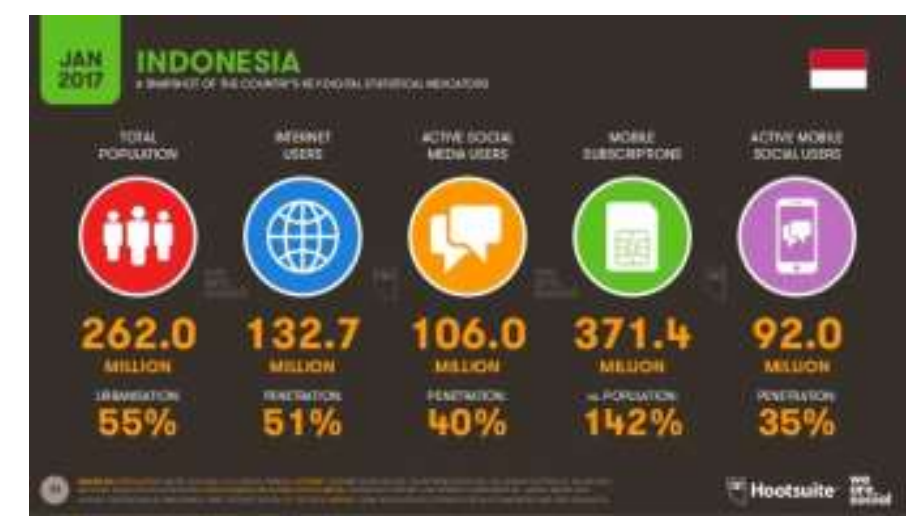

Gambar 1. Data Pengguna Internet Di Indonesia Tahun 2017

Sumber : www.internetworldstats.com

Dapat dilihat pada data diatas bahwa dari 262.0 juta penduduk di Indonesia pengguna Internet pada tahun 2017 telah mencapai hingga 132.7 juta atau 51\% dari jumlah Populasi Penduduk di Indonesia dimana kecenderungan masyarakat menggunakan media internet untuk bermain atau sekedar sosialisasi melalui media sosial yang sebelumnya telah dijelaskan. Peningkatan ini terjadi akibat dampak dari kemudahan akses informasi dan pelayanan yang lebih mempermudah segala pencarian kebutuhan pada masyarakat. Hal ini di dorong oleh penggunaan melalui alat komunikasi yang juga semakin meningkat secara fasilitas dan performa-nya, sehingga ketika masyarakat ingin mengaskses internet mereka dapat melakukan kegiatan tersebut memulalui telpon pintar nya. Dapat dilihat pada gambar diatas, peningkatan populasi masyarakat pengguna telpon pintar telah mencapai $142 \%$ atau 371.4 juta jiwa penduduk. Ini adalah hal yang tidak mengherankan lagi, karena dengan masuknya era Industrialisasi dan Modernisasi dalam perkembangan masyarakat.

Dengan demikian, berkembangnya isu-isu digitalisasi menjadi sebuah tantangan sendiri bagi semua lapisan masyarakat. Dewasa ini masyarakat tidak bisa membayangkan bagaimana hidup tanpa hal-hal yang berhubungan dengan internet ini, baik dalam berkomunikasi, sosialisasi, interkasi sehari-hari, semua dilakukan dengan media dan didorong juga semakin canggihnya teknologi sehingga masyarakat sudah terjebak jauh di dalamnya tanpa disadari. Ketika memasuki abad ke -21, rumah-rumah penduduk sudah ditransformasikan ke dalam situs budaya multimedia, mengintegrasikan audiovisual, informasi, dan pelayanan telekomunikasi. (Livingstone, 2002: 1). Hidup sudah dikelilingi dengan $e$ commerce, e-learning education, internet shopping, game online dan gaya hidup cyber lainnya. Hal ini memunculkan kekhawatiran mengenai bagaimana masa depan anak muda yang tumbuh di tengah perkembangan teknologi ini. Livingstone (2002) mengatakan bahwa ada spekuliasi mengenai 'digital generation', anak dalam 'information age', 'computer nerds', 'innocent on the Net', the'digital divide', dan 'addicted surfers'. Semua konsep di atas menunjukkan seberapa dekatnya masyarakat dengan kehidupan virtual, sehingga masyarakat berpikir ketika bisa melakukan semua hal hanya dengan duduk di depan komputer, duduk sambil bermain telepon pintar, maka kehidupan masyarakat tidak perlu pergi ke luar kamar untuk bersosialisasi dengan teman, masyarakat, dan manusia asli.

Kecenderugan ini membawa dampak pula bagi anak-anak usia remaja, dimana hal tersebut dapat mempengaruhi pola pikir dan pola tindak dari anak remaja tersebut. Semakin banyaknya kasus-kasus kekerasan yang terjadi di media dan semakin maraknya penipuan yang terjadi dalam masyarakat memberikan suatu kekhawatiran bagi perkembangan dan mentalitas anak-anak usia remaja. Dimana dalam hal ini, kategori dari anak-anak remaja adalah anak perempuan atau laki-laki yang dalam rentang usia 13 tahun hingga 18 tahun. Menariknya adalah efek dari perkembangan teknologi ini pun berkaitan dengan segala aspek kehidupan: pendidikan, gaya hidup, keluarga, konsumerisme, bahkan hingga budaya. Dimana teknologi dapat mengkaburkan batas antara kehidupan privat dan public dalam kehidupan masyarakat. Facebook dengan semboyannya "What's on your mind?" mendesak penggunanya untuk menceritakan atau mencurahkan apa yang ada di pikirannya. Perasaan yang 
kadang merupakan sesuatu yang bukan konsumsi public, mau tidak mau tanpa disadari oleh berbagai pihak diberitahukan kepada orang lain. Cara pengekspresian seperti ini lama kelamaan menjadi candu bagi para remaja ini. Daripada mengungkapkannya kepada teman, keluarga, atau orang yang bersangkutan, mereka lebih memilih "teman baru" mereka ini untuk berbagi. Hal ini disampaikan dalam materi yang diberikan oleh dosen pemateri ibu Febrimarani Malinda, S.Sos, M.A pada pelaksanaan kegiatan pengabdian Kepada Masyarakat di Sekolah menengah atas Nahdatul Ulama di Seberang Ulu I kota Palembang pada tanggal 28 Oktober 2019.

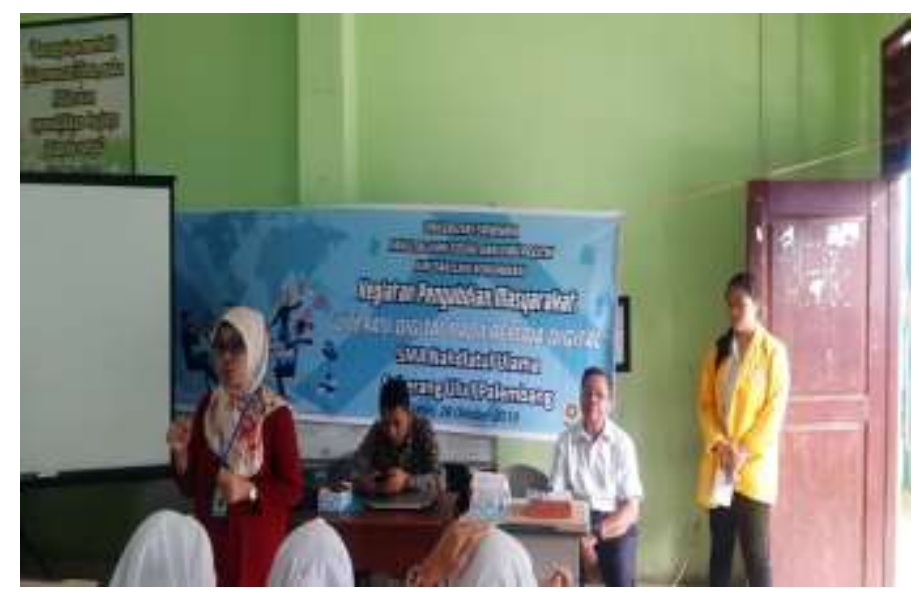

Gambar 2. Pemberian Materi Literasi Digital oleh Dosen

Piaget mengatakan bahwa secara psikologis, masa remaja adalah usia dimana individu berintegrasi dengan masyarakat dewasa, usia dimana anak tidak lagi merasa di bawah tingkat orang-orang yang lebih tua, melainkan berada dalam tingkatan yang sama, sekurang-kurangnya dalam masalah hak. Transformasi intelektual yang khas dari cara berpikir remaja ini memungkinkannya untuk mencapai integrasi dalam hubungan sosial orang dewasa, yang kenyataannya merupakan ciri khas yang umum dari periode perkembangan ini." (Hurlock, 1980). Youth atau remaja dianggap para ahli sebagai kategori sosial universal. Remaja dipahami sebagai sebuah konsep relatif yang dikonstruksikan secara budaya (Osgerby, 2004). Sheila Allen dalam Osgerby (2004) mengatakan bahwa:

"Age relation (including youth) are part of the economic relations and the political and ideological structure sin which they take place. It is not the relations between 4 ages which explain the changes or stability in society, but changes in societies which explain the relation between ages"

Dalam penelitian yang dilakukan oleh Sonia Livingstone dan Moira Bovill pada tahun 1990 menemukan bahwa remaja usia 6-17 tahun menghabiskan paling tidak 5 jam sehari menggunakan beberapa bentuk media. Sekitar 46 persennya digunakan untuk menonton televise dan sisanya untuk mendengarkan music, menonton video, bermain games, dan membaca (Osgerby, 2004). Media tidak hanya menjadi tempat pusat bagi kehidupan sosial dan budaya remaja, melainkan juga penting dalam membentuk konsep kita akan remaja sebagai kategori generasi yang berbeda (Osgerby, 2004). Seorang remaja sekarang ini paling tidak memiliki satu buah handphone dan komputer sebagai media pribadinya, selain media elektronik lainnya yang ada di rumah. Handphone menjadi sebuah barang tidak tidak dapat dipisahkan. Dengan semakin canggihnya teknologi komunikasi dan beragamanya content yang ditawarkan oleh provider, ketergantungan dan kebiasaan remaja menggunakan handphone tak terbantahkan lagi. Handphone layaknya telah menjadi budaya dalam kehidupan sosial remaja.

Dengan kata lain, semakin berkembang suatu teknologi maka semakin meningkatnya literasi pada media digital sebagai sebuah proses pemahaman bagi anak usia remaja dalam bijak menggunakan media. Literasi media digital juga menjadi bagian dari rencana jangka panjang bagi PBB yang mengurusi masalah Pendidikan dan Kebudayaan. Dan dalam rodmap UNESCO (2015-2010), literasi digital menjadi pilar penting untuk masa depan pendidikan. Literasi digital menjadi basis pengetahuan yang didukung oleh teknologi informasi secara terintegrasi. Hal ini menunjukkan bahwa pentingnya sebuah literasi dalam pemahaman oleh masyarakat terhadap segala kelebihan media digital serta harus mengetahui pula yang menjadi penghambat dalam pemahaman masyarakat dalam penggunaan media digital. 
Pada penjelasan yang dilakukan oleh pemateri, lebih menggunakan metode pendekatan dan ilustrasi yang lebih menyesuaikan dengan pemahaman siswa dan siswi dalam me-literasi media digital. Dengan peran aktif dari para siswa akan memberikan wawasan dan pemahaman bagi mereka untuk dapat memanfaatkan media digital sesuai dengan dengan fungsinya. Hal yang menarik ketika para siswa mampu merespon secara baik apa yang telah diberikan oleh pemateri, dan berbagi cerita bagaimana mereka menggunakan dan memanfaatkan media digital dalam kehidupan sehari-hari. Dengan kata lain, siswa dan siswi secara sadar telah mengetahui dampak yang dapat ditimbulkan oleh penggunaan media digital akan tetapi masih sebagian besar dari mereka belum dapat menghindari hal-hal negatif dari suguhan media digital tersebut. Contohnya saja, para siswa kecenderungannya lebih cepat menyerap hal-hal yang memiliki indikasi populeritas dari satu kelompok masyarakat, atau hanya sekedar mempercayai dan meyakini semua informasi yang sedang menjadi konsumsi publik.

Hoax dan ujaran-ujaran kebencian pada era industrialisi 4.0 ini semakin membawa masyarakat pada titik kebodohan dan ketidak layakkan media dalam menyebarkan berbagai macam informasi yang kebenarannya belum dapat dipertanggung jawabkan.

Ada beberapa kelebihan dari media digital tersebut bagi pengguna digital, antara lain adalah: pertama, secara pengaksesan informasi media digital sangat mudah, cepat dan praktis, karena dapat dilakukan dimana saja dan kapan saja. Kedua, media digital menyuguhkan berbagai bentuk informasi secara beragam, efisien dan juga efektif. Ketiga, karena untuk menjalankan media digital ini tidak perlu berada dalam suatu tempat yang besar dan luas, sudah barang tentu adanya penghematan dalam tata kelola ruang akses. Dan Keempat, dalam proses komunikasinya, media digital menawarkan bentuk komunikasi dua arah yang dalam hal ini mempermudah penyampaian persepsi dan pesan yang secara lugas dan komunikatif.

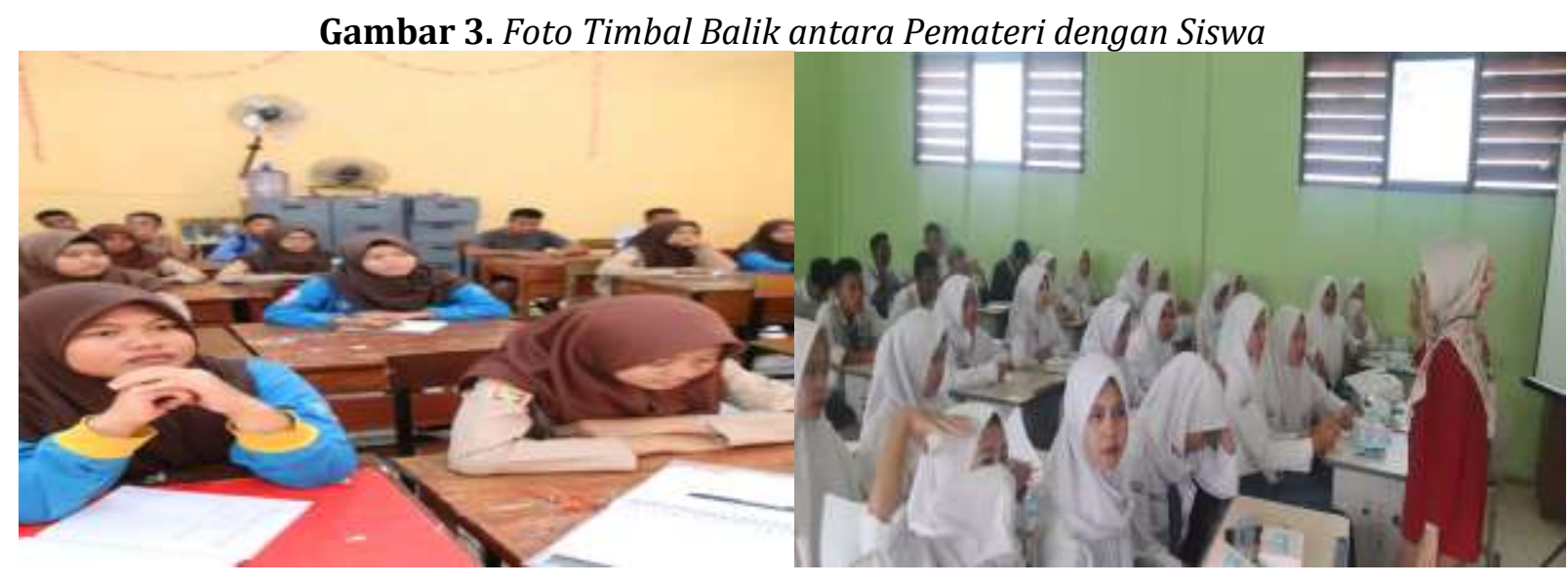

Literasi media digital ini diharapkan mampu membawa perubahan dalam pola pikir remaja terhadap penggunaan media, sehingga remaja dapat lebih bijak dalam penggunaan media digitalnya. Dalam bukunya, Riswanto (2013) berpendapat bahwa ada tiga konteks dalam pendekatan literasi digital. Pertama, konteks proteksi yang memandang bahwa pengguna internet (users), terutama anakanak dan remaja rentan terpapar konten negatif sehingga ruang daring harus diproteksi sedemikian rupa untuk mengontrol arus informasi dan penggunaan internet agar tidak menyimpang dari aturan. Dewasa ini, Indonesia menganut pendekatan ini sehingga berbagai regulasi mengenai UU ITE mengatur jalan dan perputaran roda ruang daring yang ada di Indonesia. Dengan adanya internet positif, pemblokiran konten judi dan pornografi, hingga UU mengenai hoaks menjadi sorotan pemerintah akhir-akhir ini.

Kedua, dalam konteks pendekatan instrumentalis menekankan pada penguasaan kemampuan teknis dalam menjelajah ranah dunia maya. Dan, konteks ketiga adalah pendekatan pemberdayaan yang memandang bahwa internet adalah lapak untuk memberdayakan penggunanya sesuai kebutuhan masing-masing. Pada pendekatan pemberdayaan ini pengguna internet diberikan hak kebebasan mengakses internet berdasarkan kepentingan mereka sesuai kebutuhan masing-masing. Diharapkan bagi pengguna internet untuk lebih memanfaatkan media digitalnya pada hal-hal yg berunsur kreativitas, kognitif, dan edukatif sehingga tidak perlu ada aturan ketat yang meregulasi arus dan penggunaannya. Akan tetapi, relevansi dalam pendekatan pemberdayaan hanya bisa diimplementasikan di masyarakat yang sadar dan memiliki literasi digital yang kuat. Pengguna 
internet harus memiliki kemampuan melakukan konfirmasi dan pemeriksaan ulang dalam mempertimbangkan akuntabulitas dan akurasi data, serta membaca konten berita dengan skeptis (juga kritis) dan tidak langsung menelan mentah-mentah informasi yang disajikan.

Pada akhir kegiatan pengabdian ini, selain memberikan sosialisasi tentang literasi media digital, pemateri juga memberikan kesempatan bagi para siswa dan siswi untuk berpendapat dan mengajukan beberapa pertanyaan yang cukup memberikan perhatian, antara lain ada pertannyaan tentang apa yang menjadi kegunaan media sosial.

Terdapat beberapa kelompok yang melihat bahwa remaja dapat mendapatkan literasi media tanpa bantuan dari orang lain. Sebagaimana peran dari remaja yang hidup pada masa yang lebih modern menuntun mereka untuk menguasai kompleksnya pengetahuan tentang media baru dan masih tetap melakukan praktek sosial. Menurut Jenkins (2009) terdapat tiga kelemahan dari pandangan ini: 1. Kesenjangan partisipasi (gap participants). Semua remaja tidak memiliki akses yang sama terhadap teknologi media baru dan kesempatan untuk berpartisipasi di dalamnya. 2. Masalah transparansi (transparency problems). Remaja diasumsikan secara aktif merefleksikan pengalaman media mereka dan dapat mengkomunikasikan apa yang mereka pelajari dari keikutsertaan mereka. 3. Tantangan etika (ethics challenge). Remaja diasumsikan dapat mengembangkan, dengan sendirinya, norma etika untuk berhadapan dengan lingkungan sosial yang rumit dan beranekaragam. Oleh karenanya, Literasi remaja terhadap media baru harus diawali dengan penekanan terhadap ketiga hal tersebut.

Terdapat beberapa tahapan dalam literasi media baru (Jenkins, 2009): 1. Literasi budaya media cetak. Paling tidak, remaja memiliki kemampuan untuk menulis dan membaca di media cetak. Menulis blog, jurnal, mengungkapkan opini dan membalas komentar orang lain menjadi cara awal untuk mengasah kemampuan di print culture. Literasi media konvensional ini menjadi "indera penglihatan" bagi konsumsi media baru. 2. Kemampuan meneliti. Kemampuan untuk dapat mengakses buku, artikel, menggabungkan dan menganalisis informasi, membedakan antara fakta dan opini, membangun argumen menjadi kemampuan kedua yang harus dimiliki. Dunia disajikan kepada kita dalam bahasa, simbol yang tidak hanya memiliki pemaknaan tingkat pertama. Kemampuan untuk melakukan penelitian menjadikan remaja memiliki analytical competence, menjadikannya tidak hanya bisa membaca melainkan "membaca" sesuatu hal. 3. Keahlian teknis. Mengikutsertakan keahlian digital media seperti $\log$ on, search, editing dan pengetahuan teknis yang berkaitan dengan pengoperasian media baru. Pengetahuan tentang teknis tidak boleh dianggap sepele. Perkembangan teknologi yang semakin cepat mengarah kepada tingkat adaptasi kemampuan operasionalisasi media yang cepat juga. Penguasaan yang tinggi terhadap kemampuan teknis ini harusnya juga dilengkapi dengan pengetahuan tentang terms of service yang biasanya dimiliki media baru, seperti Facebook. 4 . Studi media. Pengetahuan terhadap bagaimana media beroperasi, ekonomi media, politik, serta seluruh aspek yang menyertainya juga menjadi hal penting bagi literasi remaja. Pada kenyataannya media yang telah dikonstruksi oleh komunikatornya.

Dengan demikian sosialisasi mengenai literasi media digital ini menajadi suatu wadah dalam memberikan beberapa rujukan bagi sekolah-sekolah dan khususnya remaja dalam memahami tentang media digital dan juga memberikan informasi penting bagi pihak sekolah untuk membawa pengetahuan literasi media digital ini dalam beberapa konsep kedalam dunia pendidikan. Penjelasan secara historis, konseptual dan dimensional di atas mendudukan literasi digital dengan jelas. Keterampilan dalam bijak menggunakan media digital ini dapat meningkatkan kemampuan remaja berhadapan dengan media digital baik mengakses, memahami konten, menyebarluaskan, membuat bahkan memperbarui media digital untuk pengambilan keputusan dalam hidupnya. Jika remaja bahkan masyarakat memiliki ketrampilan ini maka ia dapat memanfaatkan media digital untuk aktivitas produktif, kesenangan dan pengembangan diri bukan untuk tindakan konsumtif bahkan destruktif.

\section{KESIMPULAN}

Literasi digital membuat masyarakat dapat mengakses, memilah dan memahami berbagai jenis informasi yang dapat digunakan untuk meningkatkan kualitas hidup seperti kesehatan dan pengasuhan anak, keluarga. Selain itu mereka dapat berpartisipasi dalam kehidupan bermasyarakat, bernegara dan berpolitik dengan menyampaikan aspirasinya di kanal-kanal tertentu. Melalui media digital, masyarakat dapat menyuarakan perspektif dan opininya demi keadilan tanpa merugikan pihak lain. 
Kesadaran awal atas karakteristik media baru dalam hubungannya dengan pengguna remaja diharapkan dapat mengurangi ekses negative terhadap dampak yang ditimbulkannya. Literasi dan etika terhadap media baru menjadi kunci bagi remaja untuk bisa memperkaya identitas serta menjaga privasi yang dimilikinya.

\section{UCAPAN TERIMA KASIH}

Akhir kata kami dari TIM Pengabdian Universitas Sriwijaya Fakultas Ilmu Sosial dan Ilmu Politik Jurusan Ilmu Komunikasi, ingin mengucapkan terima kasih atas dukungan terhadap kegiatan pengabdian ini khususnya kami tujukan ucapan terima kasih kepada Sekolah SMA NU Seberang Ulu Plaju Palembang.

\section{DAFTAR PUSTAKA}

Art, Silverblatt. 1995. Media Literacy: Key To Interprenting Media Massages. Publisher: Preager. USA.

Baran, Stanley J. dan Dennis K. Davis. 2010. Teori Komunikasi Massa Dasar, Pergolakan, dan Masa Depan. Jakarta: Salemba Humanika.

De Vito, Joseph. 2001. The Interpersonal Communication Book. Allyn and Bacon Publisher.

Jenkins, Henry. 2009. Confronting The Challenges of Participatory Culture: Media Education for the 21st Century. Illinois: MacArthur Foundation.

Livingstone, Sonia. 2002. Young People Media. London: Sage Publications.

Potter,W.J. (2005). Media Literacy. Upper Sadler River,NJ: Prentice Hall.

Riswanto, Purji. 2013. Model-Model Gerakan Literasi Media dan Pemantauan Media di Indonesia. Jakarta: PKMB dan Yayasan TIFA.

Suciati, Dr. M.Si. 2017. Teori Komunikasi dalam Multi Perspektif: Litera Yogyakarta. Mantrijeron, Yogyakarta.

Tamburaka, Apriadi. 2013. Literasi media: cerdas bermedia khalayak media massa: Amazon.com. 